\title{
Peace-Building without External Assistance: Lessons from Somaliland
}

\section{Nicholas Eubank}

\begin{abstract}
Since its secession from Somalia in 1991, the east-African nation of Somaliland has become one of the most democratic governments in eastern Africa. Yet Somaliland has never been recognized by the international community. This paper examines how this lack of recognition—and the consequent ineligibility for foreign financial assistance-has shaped Somaliland's political development. It finds evidence that Somaliland's ineligibility for foreign aid facilitated the development of accountable political institutions and contributed to the willingness of Somalilanders to engage constructively in the state-building process.
\end{abstract}

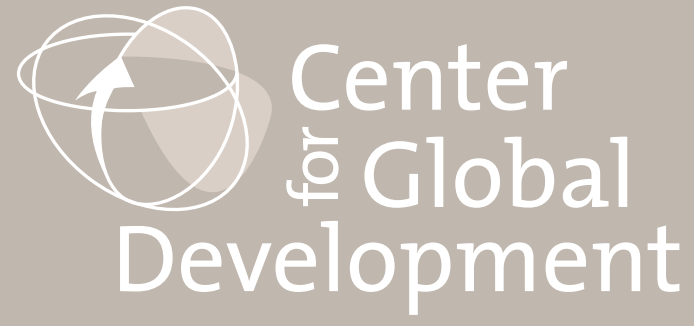

\section{Working Paper 198 January 2010}




\title{
Peace-Building without External Assistance: Lessons from Somaliland
}

\author{
Nicholas Eubank
}

This research was made possible by the generous support of the Center for Global Development's Weak and Fragile State Project. The conclusions of this paper are those of the author and are not intended to represent the views of the Center for Global Development. The arguments presented in this paper were developed over an extended period with the help of a great many people. The author is extremely grateful to Maggie Fick, Katie Krackenberger, Meredith Startz, Pierre Englebert, Abe Handler, Rachel Homer, Vijaya Ramachandran, Satish Chand, Todd Moss and participants in the Center for Global Development Fragile States Project author's conference for valuable comments and corrections. As always, any errors are the sole responsibility of the author.

This paper was made possible by financial support from the Australian Agency for International Development.

Nicholas Eubank. 2010. "Peace-Building without External Assistance: Lessons from Somaliland.” CGD Working Paper 198. Washington, D.C.: Center for Global Development. http://www.cgdev.org/content/publications/detail/1423538

Center for Global Development 1800 Massachusetts Ave., NW Washington, DC 20036

202.416.4000

(f) 202.416 .4050

www.cgdev.org
The Center for Global Development is an independent, nonprofit policy research organization dedicated to reducing global poverty and inequality and to making globalization work for the poor. Use and dissemination of this Working Paper is encouraged; however, reproduced copies may not be used for commercial purposes. Further usage is permitted under the terms of the Creative Commons License.

The views expressed in this paper are those of the author and should not be attributed to the board of directors or funders of the Center for Global Development. 


\section{FOREWORD}

I am delighted to sponsor this working paper by Nicholas Eubank, an upcoming doctoral student at the Stanford Graduate School of Business, on how the absence of international recognition and lack of direct access to official development assistance has positively affected state-building in Somaliland. The paper is commissioned as part of CGD's ongoing work on weak and fragile states, which is focused on improving the effectiveness of aid in post-conflict interventions. Eubank's paper contributes to this initiative by focusing on the potential hazards of large volumes of development assistance, including its effects on political accountability, institution building, and social-contract bargaining. Eubank examines how, in the absence of other sources of revenue, the New Charter government of Somaliland had incentives to establish credible political institutions and engage with the business community to create a tax-based relationship with its citizens to fill its coffers. The Somaliland government's inability to rely on foreign aid forced it to explore endogenous sources of revenue, inducing legitimate state-building as officials needed to be accountable to the general public, including the local business community.

Developed-country governments, as well as bilateral and multilateral institutions, have directed significant resources toward state-building and reconstruction efforts in post-conflict countries to induce security and establish political stability. Assistance in fragile and post-conflict countries is likely to grow as developed states increasingly consider such aid to be a key part of their national security strategies. But while donor money can help restore social services in a country, it may engender predation and decrease the government's need to foster relationships with its constituents. Somaliland has unique characteristics that may have contributed to this positive development outcome (such as a lack of abundant natural resources and a parity of clan representation in government), but it is a valuable case-study for policymakers. The experience suggests taking a tempered approach to aid interventions and raises interesting questions about geopolitical boundaries of what the international community considers a fragile state or a fragile situation. Political accountability and corruption are key worries in international treatment of post-conflict and failed states, and finding ways to mitigate a slide back into fragility is a must. Overall, this paper is an interesting look at a politically successful region of an otherwise anarchic state. Eubank is an exciting new voice in the debate on appropriate foreign assistance levels and international interventions.

Vijaya Ramachandran

Senior Fellow

Center for Global Development 
page intentionally blank 


\section{INTRODUCTION}

One of the largest puzzles to emerge from the recent literature on foreign aid effectiveness is the discrepancy between the findings of micro-level studies of individual aid projects and macrolevel studies of aggregate development indicators. When studies examine individual aid projects, the results are usually quite positive. Along project-specific criteria, aid interventions appear effective. At a national level, however, evidence of the impact of aid becomes elusive. This discrepancy suggests that foreign aid may have a negative "second order" effect on recipient countries beyond the impact of the actual projects it finances. These second order effects would not appear in project evaluations, but would explain the lack of evidence of effectiveness at a national level. ${ }^{1}$

Some explanations that have emerged for this irregularity focus on economic mechanisms. For instance, some have suggested that foreign assistance causes exchange rate overvaluation, reducing international competitiveness. ${ }^{2}$ Yet a growing number of statistical and qualitative studies suggest these second order effects may be political. Recent econometric studies show high aid intensity (large amounts of foreign aid as a share of the overall size of an economy) to be associated with declining quality of governance (Brautigam and Knack (2004)) and declining indicators of democracy (Djankov, Montalvo, and Reynal-Querol (2005)).

Yet despite increased attention to this issue, this literature continues to struggle with methodological issues. Because the international community has been continually and significantly involved in nearly all sub-Saharan African states since independence, there is no way to compare aid receiving states to non-aid receiving states, either cross-sectionally or intertemporally. And where variation in aid levels within or between countries exist, it is difficult to tell whether this variation is causing changes in recipient countries, or whether donors are responding to changes in recipient countries. The econometric studies cited above have attempted to adjust for this endogeneity of foreign assistance using instrumental variables, but these strategies have not achieved widespread acceptance.

The East-African nation of Somaliland provides a unique opportunity to move beyond this limitations. Somaliland was formed when it seceded from Somalia in 1991, and due to exogenous international norms against secession, it was not deemed eligible for international aid. Consequently, political actors within Somaliland have never received development assistance.

\footnotetext{
${ }^{1}$ Evidence of the discrepancies between project-level studies of aid effectiveness and studies of the impact of aid on macro-level development indicators first emerged in the mid-1990s when Peter Boone published "Politics and the Effectiveness of Foreign Aid" (Boone, 1996). In contrast to literature that came before it, Boone's paper focused on cross-country regressions using large panel data in an effort to capture the large-scale effects of aid that might have been overlooked by earlier micro-level analyses. This work launched what has come to be known as the "Third Generation" of aid effectiveness literature. This paper was later followed by the infamous Burnside and Dollar (2000) paper which found that aid had a beneficial effect in countries with a good policy environment before being refuted by Easterly, Levine, and Roodman (2004). Since then, robust evidence of aid effectiveness remains elusive. For every study that connects aid to growth (such as Clemens, Radelet, and Bhavnani (2004)), another finds no evidence of any effect (Rajan and Subramanian (2005a)). Clemens, Radelet, and Bhavnani (2004) provide an excellent overview of the evolution of this literature.

${ }^{2}$ Rajan and Subramanian (2005b).
} 
This makes Somaliland an ideal environment to examine how a lack of external financial support shapes the development of endogenous political institutions.

Yet despite occasional commentary on this subject and anecdotal evidence of Somaliland benefiting from its lack of aid, to date no systematic study has been conducted on how a lack of foreign financial resources influenced the development of Somaliland's political institutions.

This paper finds that the lack of external financial assistance to Somaliland shaped political incentives in three distinct ways. First, a lack of outside financial support increased the influence of the business community, which provided all government financing. Because pastoral economies are dependent upon stability and management of public goods like water and grazing lands, the influence of the business community has proved to be supportive of political reconciliation.

Second, with a large number of political actors with relative parity in terms of resources, a lack of outside support has forced compromise and co-option of opposition groups. Many times in Somaliland's history, small groups have tried to form a government and found themselves incapable of maintaining it - forcing the groups to expand their coalition at the cost of their own influence.

Third and most importantly, Somaliland's ineligibility for foreign assistance helped allay concerns among the general population of Somaliland about the emergence of a predatory state in Somaliland, facilitating the formation of a national government. With no foreign assistance, the Somaliland government did not have an independent revenue base, making it dependent upon the continued support of its constituents.

\section{METHODOLOGY}

These findings and the evidence that supports them is highly suggestive, but they have certain limitations. Limited international engagement with Somaliland during its early political development means that detailed accounts of political deliberations are lacking. As a result, this analysis is more dependent upon circumstantial inference than would otherwise be preferable. This fact is compounded by the fact that this study is based on a literature review and not personal field work or interviews. Moreover, in attempting to identify the impact of Somaliland's ineligibility for foreign aid, this analysis is limited by the fact the the counter-factual -- how Somaliland would have developed had it been eligible -- can never be known.

Despite these limitations, Somaliland nevertheless offers one of the only contexts in which to observe the modern evolution of political systems in the absence of foreign aid in sub-Saharan Africa, and imperfect though circumstances may be, there is still value in the study, if imperfect, of dynamics which cannot be observed elsewhere.

\section{OUTLINE}

The remainder of this chapter is organized as follows: Section 1 will provide a brief historical summary of Somaliland's political evolution to provide context for later analysis; Section 2 will 
examine the influence of the business sector on Somaliland's political development; Section 3 will examine how financial constraints affected the development of national political institutions; Section 4 will examine how Somaliland's ineligibility for financial assistance helped allay public concerns about the rise of a predatory state and facilitated political consolidation; and Section 5 will explore implications of this analysis for Somaliland and development policy in general. 


\section{SECTION 1: Brief History of Somaliland}

Somaliland owes its modern day origins to the Somali civil war against the regime of Siad Barre, which began in the early 1980s. Since coming to power in 1969, the regime of Siad Barre had grown increasingly oppressive, particularly to the northern regions of Somalia. ${ }^{3}$ So in 1981, a group of exiles from the Isaaq clan, the most populous clan in northern Somalia, formed the Somali National Moment (SNM) to challenge the regime. ${ }^{4}$

The long war against Siad Barre's government came at a high cost to the northern regions of Somalia. When the SNM took control of the major cities of Burco and Hargeysa (the future capital of Somaliland) in 1988, the response by the Barre regime was swift. "[A]rtillery and aircraft bombed the major towns into rubble and forced the displacement of roughly half a million refugees across the border into Ethiopia. Isaaq dwellings were systematically destroyed, while their settlements and water points were extensively mined."5

The war was eventually won with the disposition of the Barre regime in 1991. The victory threw southern Somalia into chaos. No single group in the region was able to secure control of the government, and conflict broke out among local militias and warlords. But while the conflict in southern Somalia is now well known, the northern regions of the country have received less international attention.

When the Barre regime collapsed in 1991, the SNM was left as the clear dominant political and military organization in the northern region. ${ }^{6}$ In May it called for a conference in the town of Burco to discuss the fate of the northern region. Elders from nearly every major clan in Somaliland gathered with the leadership of the SNM to decide on a plan of action. ${ }^{7}$

First among the SNM's challenges was re-building a region destroyed by a long fight against Barre's forces. According to a War-Torn Societies report released in 2005,

In Hargeysa [the future capital of Somaliland], a town of nearly 300,000 people, barely $10 \%$ of the structures remained intact, leaving only a vast field of blasted rubble strewn with explosives. [...] Burco, to the east, had suffered roughly $70 \%$ destruction, and countless villages in the interior had been razed to the ground. Hospitals, schools, clinics and wells had all been destroyed, government offices ransacked, bridges blown up, and roads mined and made impassable. ${ }^{8}$

Facing this tremendous rebuilding effort, some tribal elders and SNM leadership wished to consider a union with southern Somalia in a federated government, in part out of concern they would not be able to secure international support if they seceded. ${ }^{9}$

\footnotetext{
${ }^{3}$ Somaliland Centre for Peace and Development (1999), p. 16-17.

${ }^{4}$ International Crisis Group (2003), p. 6.

${ }^{5}$ International Crisis Group (2003). p. 6

${ }^{6}$ Bradbury (2008), p. 79 and 83.

${ }^{7}$ Bradbury (2008), p. 79.

8 War-Torn Societies Project (2005), p. 24.

${ }^{9}$ Bradbury (2008), p. 81.
} 
At the time of these debates, the international community was becoming increasingly concerned about the sanctity of the nation state. The US was engaging in a war with Iraq premised on the sanctity of internationally recognized borders, and events in the Balkans were leaving the world increasingly concerned about the destabilizing effect that the secession of minority groups throughout the world might bring. And nowhere was this concern more clear than in Africa, where hastily drawn colonial borders seemed to hold together states only due to intense international assertion of their importance.

But the public, fearing a return to oppression by a Mogadishu based government poured into the streets after hearing about the plan on the radio, changing "No more Mogadishu!" 10 And so in response to this pressure, Somaliland's independence was declared on May 18, $1991 .{ }^{11}$

In the hopes it would increase the chances of getting international support, the SNM decided to announce that it was not seceding, but returning to autonomy the region of Somalia that had been ruled by the British during colonial period. This region had been granted statehood for a period of four days during decolonization before agreeing to merge with southern Somalia in 1960. The SNM argued that they were not seceding, but rather nullifying the Act of Union that merged the two countries in $1960 .{ }^{12}$ The international community was strongly invested in recreating a unified Somalia, however, and these arguments were ignored. ${ }^{13}$

As the only large-scale political organization in the now independent state of Somaliland, the SNM created a transitional government built around its leadership council that was to govern from 1991 to 1993. Representatives from across the state agreed to this arrangement, and Somaliland's first government was born.

From that point forward, Somaliland's political development followed two parallel and at times intersecting tracks. On one was the evolution of national political institutions, on the other was the development of local polities that would later prove to be the building blocks of the Somaliland state.

From 1991 to 1997, Somaliland struggled to develop a national government, but repeatedly found that established institutions did not have broad enough support to be viable. Through a series of national conferences that will be explored in more detail later, political institutions eventually developed with sufficient support to govern, and in 2001 Somaliland ratified a new constitution with broad public support.

The institutions that evolved during this period survive to this day. Since 1997, Somaliland has had presidential, parliamentary, and district level elections. ${ }^{14}$ It has seen a peaceful handoff of the presidency to a minority clan president, ${ }^{15}$ and a presidential election which was decided by an

\footnotetext{
${ }^{10}$ Bradbury (2008), p. 81-82.

${ }^{11}$ Bradbury (2008), p. 81-82.

12 Bradbury (2008), p. 82-83.

${ }^{13}$ Bradbury (2008), p. 85.

${ }_{14}^{14}$ Bradbury (2008), p. 184-219.

${ }^{15}$ Bradbury (2008), p. 135-136.
} 
80 vote margin without resort to violence. ${ }^{16}$ Creating a national voter registry is proving to be a significant political and logistic problem at the moment, ${ }^{17}$ and Somaliland continues to struggle with the provision of public goods because of its weak tax base and lack of international support -- but Somaliland provides security and stability, which is more than many other internationally recognized states can claim.

Despite these successes, Somaliland's efforts to shake its secessionist label and gain international recognition have failed. As a result, the Somaliland government does not, and never has received international financial assistance, relying instead on a locally mobilized budget which has oscillated between $\$ 20$ and 40 million USD between 1999 and $2007 .{ }^{18}$ This is not to say that it does not receive any aid, only that the small amount of aid it receives is directly administered by local NGOs and aid agencies. None of the aid Somaliland receives is administered by the government or appears in the government budget. ${ }^{19}$

Accurate statistics on aid allocations to Somaliland are difficult to come by as international donors do not report the share of aid going to the unrecognized country, but the gross figure appeared to be between $\$ 30-\$ 43$ million USD in $2002 .{ }^{20}$ However, "this figure does not show the high proportion of donor funding that is spent on overhead, Nairobi offices or international personnel. Probably less than half of the total volume of aid is actually spent on the ground." 21 More recently, in 2009 Human Rights Watch reported that Somaliland's government estimates that the region receives approximately $\$ 79$ million USD per year. ${ }^{22}$ To put these numbers in context, Somaliland's population is estimated at 2-3.5 million people, earns around $\$ 180$ million USD a year in export earnings, and receives an estimated \$200 million USD a year in remittances according to that same report.

Even without international support, Somaliland's economy, which is built primarily around pastoral farming and animal husbandry, has largely recovered from the devastation of years of conflict. $^{23}$ Somaliland has rebuilt many of the cities destroyed during Somalia's civil war, and economic activity in much of the country is thriving. As Bradbury (2008), has noted:

Over the past fifteen years, the cities, small towns, and villages have been substantially rebuilt and expanded. Commercial activity is vibrant. Utilities have been restored, telephone systems have been established linking Somaliland into the world-wide web, where numerous Somaliland websites can now be accessed, and Somali companies have established services throughout the country that

\footnotetext{
${ }^{16}$ International Crisis Group (2003), p. 23-25. Nearly half a million ballots were cast.

${ }^{17}$ A detailed summary of Somaliland's current struggles with these issues can be found in International Crisis Group (2009).

${ }^{18}$ Bradbury (2008), p. 236-237 provides data up through 2003, while Somaliland Ministry of Planning and Coordination (2008) provides more up to date data.

${ }^{19}$ War-Torn Societies Project (2005). p. 100.; Ministry of Planning and Coordination (2008), p. 13.

${ }^{20}$ Bradbury (2008), p. 157. provides the estimate of \$43 million, while International Crisis Group (2003), p. 6-7. provides an estimate of $\$ 30$ million.

${ }^{21}$ International Crisis Group (2003), p. 6-7.

${ }^{22}$ Human Rights Watch (2009), p. 55.

${ }^{23}$ Bradbury (2008), p. 138-139.
} 
facilitate financial transfers from anywhere in the world to the smallest village in Somaliland. ${ }^{24}$

Statistical data on Somaliland is exceedingly scarce, making objective confirmation of these accounts difficult, ${ }^{25}$ but what data does exist suggests significant improvements in the region since Somalia's civil war. Government data on school enrollment, for example -- the only available data on Somaliland collected as far back as the 1990s -- shows significant improvement in the region. Somaliland has established six new universities since 1995, when the region had none, ${ }^{26}$ and primary and secondary school enrollment has improved for both boys and girls as shown in Figure 1. ${ }^{27}$ These numbers mask the same urban biases found in many developing countries and the fact that schools remain prohibitively expensive for many poor families, ${ }^{28}$ but the improvement in availability over such a short period is itself remarkable.

\section{Figure 1}
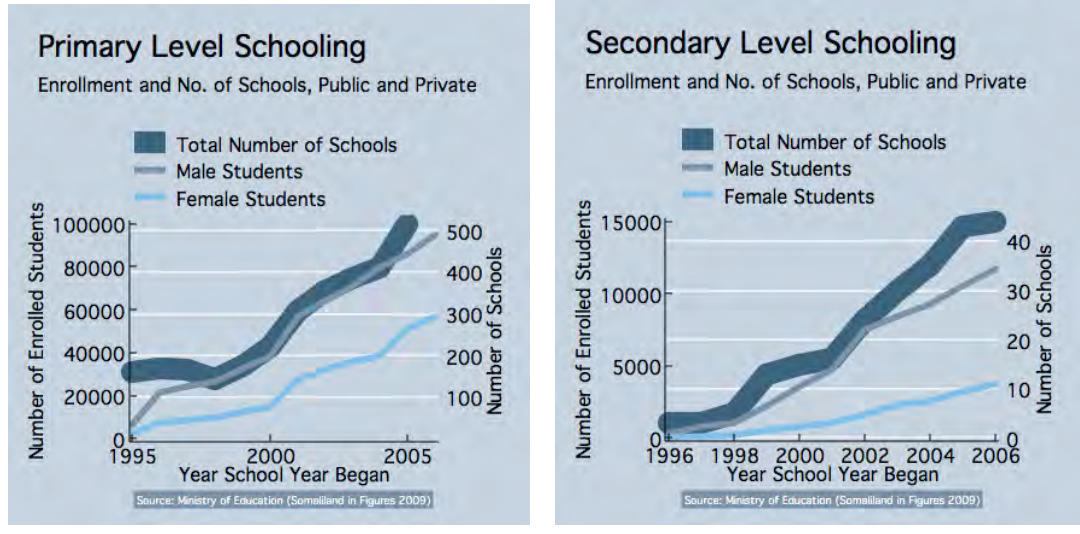

Available data also strongly suggests Somaliland is doing significantly better than southern Somalia, a significant reversal of the pre-civil war income distribution in the region. A 2002 UNDP/World Bank household survey finds that the regions of Somaliland have significantly higher incomes than regions of southern Somalia. ${ }^{29}$ A very crude extrapolation of the survey's results suggests an average income of \$300 USD per capita in Somaliland, compared to an average income of \$225 USD when all of southern Somalia and Somaliland are examined together. (Estimates for "Somalia" presented by the UNDP and World Bank continue to include

\footnotetext{
${ }^{24}$ Bradbury (2008), p. 137.

${ }^{25}$ The limited availability of data on Somaliland comes from two sources. The first the lack of surveys conducted in Somalia during the 1990s. The 2003 UNDP/World Bank cited above constituted the first multi-sectoral nationwide household survey conducted in greater Somalia (southern Somalia and Somaliland) in two decades. The second source of limited data comes from the continued treatment of southern Somalia and Somaliland as a single country by the international community even when collecting statistical information. Some reports, like those cited above, break down data by colonial regions, but there are imperfect categories at best.

${ }^{26}$ Somaliland Ministry of Planning and Coordination (2004), p. 58 and Somaliland Ministry of Planning and Coordination (2008), p. 54.

${ }^{27}$ Beyond this school data, the Somaliland government does not provide any statistics over extended time periods which might be useful as measures of economic activity or social service provision aside from government expenditure data (which is explored in more detail later).

${ }^{28}$ Bradbury (2008), p. 165.

${ }^{29}$ UNDP/World Bank (2003), p. 23.
} 
Somaliland as a part of Somalia). ${ }^{30}$ The few health statistics that are available specifically for Somaliland also suggest that the country is doing better than the rest of Somalia, although Somaliland's indicators still leave much to be desired. For example, the infant mortality rate in Somaliland was half the average of all of Somalia and Somaliland in 2000 (113 versus 224 deaths per 1,000 live births). ${ }^{31}$ To some degree this comparison to southern Somalia sets a relatively low bar, but in a region of failed states, brutally repressive regimes, and brazen electoral fraud, Somaliland's accomplishments are, in the words of a recent Human Rights Watch report, "both improbable and deeply impressive.",

\footnotetext{
${ }^{30}$ UNDP/World Bank (2003), p. 23. Estimate derived by simple average of the five regions the make up Somaliland, as population data by region is not available for calculating weighted averages. Estimates for these regions are relatively tightly clustered between approximately $\$ 275-\$ 350$ per capita, however, making an estimate of $\$ 300$ a reasonable approximation. There is no way to account for the fact that only parts of Sool and Sanaag are a part of Somaliland, however.

${ }^{31}$ Bradbury (2008), p. 162. A good survey of all available statistics on Somaliland can be found in Bradbury (2008) from pages 160-183.

${ }^{32}$ Human Rights Watch (2009), p. 2.
} 


\section{SECTION 2: POLITICAL ROLE OF THE BUSINESS COMMUNITY}

One of the main concerns voiced in literature on the possible negative effects of foreign aid is that foreign assistance may decrease government dependence on tax revenues. This may be detrimental for two reasons: one, it may decrease the incentive of the government to promote positive economic development, as its revenue base is less tied to overall economic activity; and two, it removes an important mechanism by which citizens can demand accountability from the government. Because citizens and businesses can resist taxation, and by doing so increase the costs of tax collection, decreasing its efficacy, dependency on tax revenue creates a de facto mechanism of accountability which can be employed even in the absence of effective de jure accountability arrangements. Resisting taxation deprives the government of revenue, weakening it. But if the government has a non-tax based source of revenue, this type of resistance becomes ineffectual. ${ }^{33}$

With this in mind, one of the most remarkable impacts of Somaliland's international isolation is the degree to which that isolation increased the political influence of the local business community. In the absence of international financial support and of developed natural resources, both local polities and Somaliland's national government relied on local business communities for financial support, either in the form of direct loans to the government or commercial taxation. This dependency has endowed the commercial sector in Somaliland with a great deal of influence vis-a-vis the government -- influence which appears to have had a beneficial effect on Somaliland's political development.

This influence has been well noted among observers of Somaliland. Bradbury has called the relationship between the business community and the government in the mid-1990's a "relationship of co-dependency." 34 De Waal goes as far as to characterize the government of Somaliland as a "profit-sharing agreement among the dominant livestock traders, with a constitution appended," although this view does not do justice to the popular support for the Somaliland government. ${ }^{35}$

It is not difficult to see why the influence of the business community has been characterized in this way. Not only has the private sector has provided nearly all financing for the series of local polities that developed throughout Somaliland before the establishment of a truly national government, they also provided nearly all financing for the numerous (by one count at least 32 ) ${ }^{36}$ national, regional, and local peace conferences that were held across Somaliland between 1991 and 1997. ${ }^{37}$ These conferences consisted both of local conferences that helped settle local disputes and lay the groundwork for larger, national conferences, and the national conferences themselves.

\footnotetext{
${ }^{33}$ Both Moss, Pettersson and van de Walle (2006) and Moore (2008) provide exceptional and more extensive overviews of existing literature on this subject.

${ }^{34}$ Bradbury (2008), p. 155.

${ }^{35}$ De Waal (2007). p. 13 of 19.

${ }^{36}$ War-Torn Societies Project (2005). p. 64

${ }^{37}$ Bradbury (2008), p. 98. One notable exception is the series of national reconciliation conferences held in 1997 , which was mostly financed by the government itself (Bradbury, (2008), p. 125.).
} 
This influence manifested in variety of ways, some readily visible, some less so. When a transitional government was created in Boorame in 1993, the business community loaned the government \$6-7 million USD, a critical source of funds at the time. Even after this initial loan was repaid in 2000 , the private sector has continued to provide the government with loans. ${ }^{38}$

The business community also played an active role in demobilizing by providing rations to demobilized militia members ${ }^{39}$ and to a new government army and police force. ${ }^{40}$ And when Somaliland's fragile peace was upset by fighting over Somaliland's main port, businessmen who relied on the port for export of livestock were an active voice for peace. Both De Waal ${ }^{41}$ and Bradbury make this point, with Bradbury pointing out that:

Concerned with the commercial consequences of the fighting in Berbera in 1992, [Isaaq businessmen, the wealthiest of whom were based in Djibouti] subsequently played an important role in restoring stability by funding peace conferences, providing resources for demobilization and the new security services, and underwriting the state by providing loans to the administration. ${ }^{42}$

Other impacts are more subtle. As already noted, Somaliland's national government was built upon the foundation of agreements made by local polities, which were also supported by local commercial groups. Bradbury (2008) notes that the agreements made by these local polities were exceptional for the degree to which they focused on what he refers to as "civil issues," like freedom of movement, water and grazing rights, and private property definitions, all critical to a pastoral economy. There was a "synergy between the Somaliland-wide peace conferences and the local peacemaking processes, which succeeded in containing violence while crafting a political consensus and power-sharing agreements that provided the foundations for new state structures." 43

Commercial interest played a large role in motivating local polities to address civil issues. As a result of the pastoral nature of the region's economy, cooperation and stability are viewed among Somalilanders as prerequisites for economic prosperity. This view is embodied "by the Somali saying nabad iyo caano ('peace and milk' or 'peace and prosperity'), which [...] stands in opposition to the phrase ol iyo abaar ('conflict and drought')." ${ }^{, 4}$ Bradbury (2008) makes this point quite eloquently:

Access to pasture and water is assured through peaceful cooperation. Access to land and its usage was an underlying issue in the civil war in Sanaag and a driving force behind peace there. In order for people to survive and resume their way of life there was a need to re-establish cooperative relations over pastoral resources and trade. The series of peace meetings that were concluded prior to the Erigavo

\footnotetext{
${ }^{38}$ Bradbury (2008), p. 155.

${ }^{39}$ Bulhan (2004), p. 101.

${ }^{40}$ Bradbury (2008), p. 112.

${ }^{41}$ De Waal (2007), p. 13 of 19.

${ }^{42}$ Bradbury (2008), p. 94.

${ }^{43}$ Bradbury (2008), p. 107.

${ }^{44}$ Bradbury (2008), p. 103.
} 
conference set out the parameters for peaceful cooperation: freedom of movement; freedom of trade; access to common grazing areas; access to common water sources; and the return of private property.. ${ }^{, 5}$

More recently, the private sector has also emerged as a key player in the provision of public goods in Somaliland. Because of tight budget constraints, only $10 \%$ of the national government of Somaliland's limited budget is allocated for social spending, ${ }^{46}$ but public-private partnerships have helped to fill the void left by the government's limited capacity. These partnerships include things like:

management of municipal water supplies, [...], the Universities of Amoud, Hargeysa and Burco, and Edna Adan Maternity Hospital, which are funded through a mixture of donations from the diaspora, fees, government subsidies, and corporate sponsorship. ${ }^{47}$

Businesses in Somaliland contribute to social services more directly. "Companies have always been obliged to pay zakaat (alms), but some of the newer, larger companies are contributing to development projects," further suggesting a positive role in Somaliland's development. ${ }^{48}$

Of course, this is not to suggest that there are not downsides to the major role of the business community in Somaliland. Most notably, dominant Isaaq businessmen, who provided many of the direct loans to the interim government in 1993, were rewarded by a monopoly over the regional livestock market, which has raised the ire of smaller middle-level traders. ${ }^{49}$ Further, the fact that 'the line between what is 'public' and what is 'private' is ambiguous" limits the ability of the government to objectively regulate the private sector. ${ }^{50}$ Yet on the whole, the role of the business community in Somaliland appears to have been to its benefit.

\section{Influence of Commercial Interests and Foreign Assistance}

It is impossible to say with certainty how much influence the private sector would have had if Somaliland had been eligible for foreign assistance. What is clear, however, is that had Somaliland been eligible for financial assistance, international assistance would have dwarfed the financing provided by the private sector, removing the private sector's financial leverage.

Between 1991 and 2004, the median sub-Saharan African country received an average of roughly \$47 USD per capita (in constant 2005 dollars). At that level, Somaliland would have been eligible for approximately $\$ 94$ million USD based on a conservative population estimate of 2 million. To put this in context, that amount is more triple annual Somaliland government revenues, which have ranged between \$20 - \$40 million USD between 1999 and 2009, and

\footnotetext{
${ }^{45}$ Bradbury (2008), p. 103. This comes from a passage describing the Sanaag Grand Peace and Reconciliation Conference in 1993, which Bradbury calls "a classic example of a peace process that addressed civil issues." (p. 101). 
which were even lower in preceding years. ${ }^{51}$ (A more detailed investigation of the likely nature of aid policy toward an eligible Somaliland is presented in Appendix One of this paper.)

This strongly suggests that had Somaliland been eligible for foreign assistance, the public sector would have been far less financial dependent upon commercial interests, and Somaliland's political development may have followed a very different path.

\footnotetext{
${ }^{51}$ An extended discussion of this and alternative imputations can be found in Appendix One, but in most every respect, this estimate is quite conservative. It uses median rather than mean aid levels, a conservative estimate of Somaliland's population, and it does not take into account the tendency for aid agencies to provide more aid per capita to smaller countries.
} 


\section{SECTION 3: DEVELOPMENT OF NATIONAL INSTITUTIONS}

The development of Somaliland's political institutions also appears to have been influenced by its international isolation. One of the most exceptional aspects of Somaliland's political institutions is the degree to which they provide real representation to all parties in the country. In fact, as of 2005, Somaliland is "one of the only governments in Africa with 'cohabitation' between rival parties in the executive and legislative branches."

One reason given for this development is the role of traditional institutions. Somaliland has garnered significant attention for the central role that indigenous conflict mediation techniques have played in each of the many peace conferences that have occurred across the country, and for the fact that one of the two houses of the Somaliland legislature is built around traditional clan representatives. But while it is clear that these techniques facilitated conflict mediation, parties in the country approached the negotiating table only out of necessity after military options had failed. This suggests that while traditional institutions were important, their role was largely one of mediators, negotiating compromises forced by political necessity. ${ }^{53}$

In the two cases where necessity forced transitional governments to negotiate with opposition groups, Somaliland's eligibility for foreign assistance would likely have resulted in international support for the transitional governments, which would have undermined the prevailing condition of parity that forced political compromise. Had these compromises not been forced, Somaliland's government might not be the widely supported durable set of institutions it is today.

\section{Failure of the SNM Transitional Government}

Somaliland's efforts to establish a national government got off to an inauspicious start with the SNM-based transitional government established in 1991. In part due to internal divisions, and in part due to a lack of resources, the SNM was never able to project authority beyond the territories of the clans that made up its core membership. As the organization struggled to government, it became clear that the SNM had largely been held together by a common distaste for the military regime. With the war over, financing from the diaspora -- which had helped support the SNM during the civil war -- dried up, and the group succumbed to internal divisions. ${ }^{54}$ In the words of an ICG report:

[SNM transitional President Abdirahman Ahmed Ali 'Tuur'] governed mainly from behind closed doors, and his impoverished administration exerted little real

\footnotetext{
${ }^{52}$ Menkhaus (2006/2007). p. 92.

${ }^{53}$ Menkhaus (2001) makes a similar point, arguing that "To the extent that the role of traditional elders is to represent their community in peace talks, their ability to promote peace is constrained by the material interests of the communities to which they belong. Analysis of the motives and interests of traditional peacemakers must be rooted in an astute assessment of their constituencies." (Menkhaus (2001), p. 197.) De Waal (2007) makes a related point in his analysis of Somalia, arguing that "the clan system in contemporary Somalia should be seen primarily as a means of organizing political and economic life that is driven by other interests, rather than the determining factor for Somalia's political economy." (De Waal (2007), p. 1 of 19)

${ }^{54}$ Bradbury (2008), p. 85-86.
} 
control, even of the capital city of Hargeysa. Within a matter of months, the SNM began to suffer from the kind of factionalism more often associated with southern Somali political movements. As tensions within the SNM came to a head, even the illusion of control evaporated and in January 1992, the Movement went to war with itself. ${ }^{55}$

Limited representation within the new SNM government quickly led to problems. Many felts that the administration was being dominated by the clan of the President, the Habar Yonis. ${ }^{56}$ One such Isaaq clan was the Habar Jelo, a traditional rival of the president's clan that had held its peace during the civil war. This clan broke off from the SNM administration and began an opposition group. ${ }^{57}$ In early 1992, government attempts to bring heavy weapons under its control in the town of Burco sparked heavy fighting with between the government and this opposition group, which left over 300 people dead. ${ }^{58}$ But given its limited resources, the SNM was unable to assert its authority over this opposition group.

(Please note that from this point forward, this analysis will use these clan two clan names despite the occasional involvement of additional groups in political conflicts. This simplification does not change the interpretation of events significantly, and helps to make this paper accessible without entering into an extended discussion of clan structure). ${ }^{59}$

In 1992, the SNM government attempted to take control of Somaliland's port of Berbera in order to broaden its revenue base, a move motivated in part by a desire to raise a national army ${ }^{60}$ Berbera is Somaliland's main port, and would eventually become one of the government's main sources of revenue. ${ }^{61}$

At the time, however, the port of Berbera was controlled by an Isaaq clan which was not well represented within SNM government, the ,Ilse Muse. This group "disliked the move, which they saw as an attempt by the [President's Habar Yonis clan] dominated government to appropriate power and the tax revenue of their port facility." 62 This clan resisted the SNM's attempt to administer the port militarily, and was quickly joined by the Habar Jelo opposition faction. ${ }^{63}$ The resulting conflict over the port lasted for five months, and caused the death of more than 600 Somalilanders. $^{64}$

\footnotetext{
${ }^{55}$ International Crisis Group (2003), p.9.

${ }^{56}$ Farah and Lewis (1993), p. 54-55.

${ }^{57}$ Farah and Lewis (1993), p. 54-55.

${ }^{58}$ Bradbury (2008), p. 89.

59 At times the parties involved in conflicts are actually larger groups to which the Habar Yonis and Habar Jelo belong. For example, Habar Yonis is sometimes used when the Iidagale should also be included. Habar Jelo is occasional used when it would be more accurate to say Habar Awal, a larger group to which the Habar Jelo belong. This simplification does not change the interpretation of events significantly.

${ }^{60}$ Bradbury (2008), p. 88-89.

${ }^{61}$ Bradbury (2008), p. 111

${ }^{62}$ Farah and Lewis (1993), p. 55.

63 Bradbury (2008), p. 89.

${ }^{64}$ Bradbury (2008). More than 600 is inferred from references to the combined death toll of the Burco and Berbera conflict being more than 1000 (p. 87) and the later statement that more than 300 were killed in the fighting in Burco (p. 89).
} 
In an open letter released during the conflict, the ,Ise Muse port stated that "Berbera is one of the districts of the Republic of Somaliland and is therefore subject to its rules and regulations," and that " $[\mathrm{w}] \mathrm{e}$ are ready to participate in a genuine national economy, national force and national law and order structure," but that it would "never accept a special military force and rule designed for Berbera alone." 65

The conflict eventually drew to a close after the ,Ise Muse headed opposition groups had repulsed the SNM forces, re-secured their control over the port, and was advancing on Hargeysa, the SNM capital. "66 "Facing military defeat and public opposition, [the president of the SNM government] accepted the need to enter dialogue with the opposition," 67 and a series of national peace conferences were called.

\section{Creation of Accountable and Representative Institutions}

What followed was a series of three peace conferences. These conferences, which took place over a period of 8 months between 1992 and 1993, were "almost entirely financed by the communities of Somaliland, who thus determined the agenda." ${ }^{68}$ At the end of these conferences, what emerged was a more inclusive and representative government built around a new National Charter. The new government included a parliament that consisted of 150 clan elders, and a new president and vice president. ${ }^{69}$ Critically, this new government differed from the SNM government in that it,

"possessed a broader base in terms of political participation and representation, although the smaller and minority clans were not represented at the Boorame Conference, non-Isaaq clans were given better representation compared to the previous administration., 70

These conferences also resulted in the appointment of a new president, whose paternal lineage came from the ,Ilse Muse clan -- which had controlled the port of Berbera -- and whose maternal lineage came from the Habar Yonis clan -- which had previously been represented by the presidency. This "encouraged public optimism that [the new president] could unite the Isaaq."71 The new president also had the benefit of being the "favoured candidate of the dominant Isaaq businessmen." 72

The government created by the new National Charter also divided the government into an presidential executive, an independent judiciary, and a bicameral legislative branch. ${ }^{73}$ As already noted, this legislative branch included one house made up of traditional clan elders who

\footnotetext{
${ }^{65}$ Farah and Lewis (1993), p. 56-57.

${ }^{66}$ Bradbury (2008), p. 90.

${ }^{67}$ Bradbury (2008), p.90.

${ }^{68}$ Bradbury (2008), p.98.

${ }^{69}$ War-Torn Societies Project (2005), p. 62-63.; Farah and Lewis (1993), p. 55-58.

${ }^{70}$ War-Torn Societies Project (2005), p. 64.

${ }^{71}$ Bradbury (2008), p. 110.

${ }^{72}$ Bradbury (2008), p. 155.

${ }^{73}$ Bradbury (2008), p. 99-100.
} 
represented all clans in Somaliland. This house, which was created "to guard against the reemergence of authoritarian rule," 74 was given authority to appoint the president and vicepresident. $^{75}$ (The presidency would later become an independently elected office).

As a result of these conferences the new government earned "the backing of some of Somaliland's wealthiest merchants, who had interests in keeping Berbera free of conflict,"76 and the port of Berbera was placed under the control of the government, which "provided an immediate revenue source for government [sic], which by September 1995 was estimated to be between US\$10-15 million per year.",77

\section{Second Cycle of Violence}

While the conferences held in Boorame in 1993 laid the foundation for all subsequent political institutions in the country, they did not represent the end of the development of Somaliland's political institutions. Unfortunately, Somaliland underwent one subsequent cycle of violence before achieving some degree of democratic consolidation.

Somaliland's new National Charter established a framework of accountable and representative institutions, but it was not embraced by all. The Habar Yonis, who had previously held central authority within the SNM transitional government broke with the government over disagreements about representation ratios. ${ }^{78}$ In 1996, the conflict reached a stalemate, but initially neither the government, nor opposition groups showed any willingness to compromise.

What exactly motivated the government to reach a compromise with the opposition is not entirely clear, but it appears to have been motivated by a combination of pressure from civil society and the strain the conflict was putting on the government's limited resources.

In 1995 a group of Somalilanders living abroad organized the Peace Committee for Somaliland, began pushing for a peaceful resolution. This group organized a series of intra- and inter-clan peace conferences to promote dialogue between different groups and organize for peace. ${ }^{79}$ The Committee also appears to have won the backing of Ethiopia, which encouraged rival groups to attend conferences out of concern Somaliland's conflict might spill over the border. ${ }^{80}$

The exact impact of this organization is "contested," 81 but it is clear that the committee facilitated discussion between various factions. It appears that in the view of some, however, the role of the Peace Committee and civil society more broadly was much greater. One analyst -who founded the Peace Committee for Somaliland in 1995 and was thus intimately involved in deliberations at the time -- has expressed the view that:

\footnotetext{
${ }_{75}^{74}$ Bradbury (2008), p. 224.

${ }^{75}$ Bradbury (2008), p. 100.

${ }^{76}$ Bradbury (2008), p. 110.

${ }^{77}$ Bradbury (2008), p. 111.

${ }^{78}$ International Crisis Group (2003), p.11.; Bradbury (2008), p. 116-117.

${ }^{79}$ Bradbury (2008), p. 121-123.

${ }^{80}$ Bradbury (2008), p. 122-123.

${ }^{81}$ Bradbury (2008), p. 122.
} 
The war would have continued if pressure for peace and reconciliation did not come from civil society, first from Somalilanders living in the Diaspora, then from traditional elders, intellectuals, and former civil servants in Somaliland. [President] „,Egal and his government agreed to dialogue and negotiations when they could no longer contain a peace movement that grew rapidly by [1996] and could have swept them from power if they remained intransigent. ${ }^{, 82}$

This pressure combined with the significant strain the conflict was putting on the government's limited revenue base. It is estimated that the government spent $\$ 4.5$ million USD re-equipping the army during the conflict. ${ }^{83}$

Together, these forces were apparently sufficient to push the government towards reconciliation. A second series of national conference was called, this time incorporating 315 elders, more than double the number included in the Boorame conference. A new provisional constitution was adopted, and the allocation of seats within the government was adjusted in a manner with increased the representation given to the Habor Yonis, and the conflict was diffused. ${ }^{84}$

After six years of conflict and fighting, the power-sharing arrangements established by the Hargeysa Conference proved sufficient to quell further uprisings. From this point forward, political conflict in Somaliland shifted to the electoral arena. In 2001 a constitutional referendum was held, and the provisional constitution created in Hargeysa was replaced with a new constitution. This constitution was finalized in 2000 by a committee composed of individuals nominated by both the legislative and executive branches, was ratified in a national vote in 2001, and is still in place today. ${ }^{85}$

\section{Foreign Assistance and Forced Negotiations}

By most international standards, both the SNM transitional government and the Boorame conference were legitimate national governments, and would have likely been eligible for international assistance had Somaliland been a recognized state. They were created at a national conferences with the consent of clan elders from across the region, and by those agreements had the "right" to administer the Port of Berbera and the Hargeysa airport. Yet had the international community stepped in and provided support to either of these governments, it is not clear that either would have submitted to negotiations with the opposition. Indeed, the fact that political compromises followed failed attempts by the government to assert its authority by force certainly suggests the government had no interest in engaging in political negotiations until it was necessary.

It is especially noteworthy that in the first conflict, the governments efforts were motivated by a desire to control a port worth only \$7-15 million USD -- less than one sixth the foreign assistance Somaliland would likely have received had it been eligible, even by conservative

\footnotetext{
${ }^{82}$ Bulhan (2004), p. 44.

${ }^{83}$ Bradbury (2008), p. 116.

${ }_{85}^{84}$ War-Torn Societies Project (2005), p. 66-67.; Bulhan (2004), p. 44.

${ }^{85}$ War-Torn Societies Project (2005), p. 68-70.
} 
estimates. This strongly suggests that had the government been receiving anything approaching normal levels of financial assistance, it would not have been put in a position where it was forced to compromise with the ,Ise Muse. 


\section{SECTION 4: POLITICAL UNIFICATION AND THE PROMISE OF AID}

While relative parity ensured that a national government provided adequate representation to all parties in the country, the willingness of anyone in Somaliland to support the creation of a national government is itself remarkable. From colonial exploitation in the 1800 s to the tyrannical rule of the Siad Barre regime, the state has proven to be anything but a force for good in the experience of the average Somali. Yet Somaliland's government has broad public support, and Bradbury (2008) has argued that "[i]n many respects Somaliland is a 'people's project' rather than a project of an elite." ${ }^{\prime 86}$ This achievement was made possible in part thanks to the decentralization of Somaliland's government, but also in part by the fact Somalilanders did not have to worry about a government with a large, independent source of resources in the form of foreign aid.

The degree to which Somali's conception of the state has been shaped by historic events is best explained by Ken Menkhaus (2006/2007), a long time observer of Somali politics:

There is perhaps no other issue on which the world-views of external actors and Somalis diverge more than their radically different understanding of the state. For external actors, the conventional wisdom is that a responsive and effective state is an essential prerequisite for development, a proposition enshrined in virtually every World Bank and UN strategy on development. For many Somalis, the state is an instrument of accumulation and domination, enriching and empowering those who control it and exploiting and harassing the rest of the population. ${ }^{87}$

This concern is common to all Somalis, but it is particularly acute among the Somalilanders, who suffered disproportionately under the military regime in Mogadishu.

Somalilanders' concern about the emergence of a predatory state most clearly manifested itself in the push for decentralization in the design of the government. As John Drysdale, a longtime observer of Somali politics, noted:

The intention of the authors of the [1993 Transitional National] Charter was clearly inspired by their wish to maximize the process of political devolution, given that the majority of Somalilanders had suffered grievously over the past two decades from manifold abuses of power arising out of a highly centralized state system of government in Muqdisho. ${ }^{88}$

A 2005 War-Torn Societies report on Somaliland similarly found during focus groups that:

Many Somalilanders, particularly those beyond Hargeysa, deem decentralization to be an inescapable condition for their participation in Somaliland's political arrangement. ${ }^{89}$

\footnotetext{
${ }^{86}$ Bradbury, Mark. Becoming Somaliland, 2008. p. 248.

${ }^{87}$ Menkhaus (2006/2007), p. 87.

${ }^{88}$ Drysdale (1995) quoted in War-Torn Societies Project (2005). p. 88.

${ }^{89}$ War-Torn Societies Project (2005). p. 87
} 
Today, Somaliland has a federal government, divided into the central government, regional councils, and district councils. Independent elections are held at all levels, and some degree of fiscal decentralization is also maintained. Although customs collection was centralized in 2000, districts retain $10 \%$ of customs collections that occur within their borders and receive an additional $12.5 \%$ of pooled collections from the central government. Districts are also able to raise their own revenues by "taxing local resources, with land, animal slaughter and business tax providing the main revenue streams." ${ }^{.90}$ Aggregate data on district government expenditures suggests that these measures provide districts with a relatively high degree of fiscal independence from the national government, while also ensuring that districts maintain a financial dependency on local communities. ${ }^{91}$

Even with this extensive decentralization, however, there is reason to doubt whether Somaliland would have been able to overcome skepticism about state had it been eligible for foreign assistance. As de Waal (2007) points out, foreign aid has long been a historic enabler of state predation for Somalis:

Somalia was Africa's largest per capita recipient of international aid in Africa (with the exception of micro-states such as Gambia) [during the 1980's]. These huge inflows of aid money, especially from the U.S., made it possible for the Siad Barre government to establish a patrimonial system wholly disproportionate to the productive economy. Indeed, it was the aid flows that made possible the strategy of assaulting the productive sectors such as agriculture and livestock. ${ }^{92}$

In other words, not only are Somali's deeply skeptical of the western state, but they also associate state predation with foreign assistance. With this in mind, Somaliland's ineligibility for foreign assistance was likely a major advantage for efforts to establish a national government. Ineligibility ensured that Somalilanders would continue to maintain a de facto mechanism of accountability in the form of financial dependency of a national government on tax revenues.

\footnotetext{
${ }^{90}$ Bradbury (2008), p. 238. Unfortunately, data on the relative contribution of these different sources of local revenues is not available.

${ }^{91}$ The de facto degree of fiscal decentralization appears to vary by district. Total local revenues from across Somaliland are relatively correlated with total central government revenues, suggesting that in terms of revenue, many districts are dependent upon the national government. But revenues for a variety of local polities based in major cities show a great deal of independence. Graphs can be found in Appendix Two.

${ }^{92}$ De Waal (2007), p. 9 of 19.
} 


\section{CONCLUSIONS}

This analysis has implications both for aid-policy towards Somaliland and for broader debates on state-building strategies.

\subsection{Implications for International Policy Towards Somaliland}

The discussion presented in this chapter bears directly on debates over international recognition of Somaliland. It cannot answer whether Somaliland is deserving of international assistance, or, as some have argued, if recognizing Somaliland will lead to increased conflict in the rest of subSaharan Africa (as other groups are motivated to secede). What this analysis does suggest, however, is that the international community should be extremely cautious about flooding Somaliland with financial assistance, as doing so might undermine the relationships of financial accountability that have played such a large role in Somaliland's success. While this paper's focus has been on Somaliland's early political development, recent statements by international observers suggest that some of the same dynamics that are explored in this paper continue to be important today. As a 2009 Human Rights Watch report states (after detailing some of ways Somaliland's president has not always been effectively limited by constitutional limits):

Somaliland's government remains fundamentally a product of political compromise, negotiation, and consensus and the presidency is often not strong enough to defy the diverse coalition of clan and other interests that support it. This reality imposes informal limits on presidential power which have worked well enough to partially offset the dysfunction of legal and constitutional constraints. [...] The result, as another analyst put it, is that "Some in the government don't believe in our democratic process, but no one has enough power to destroy it." 93

Providing the government with significant financial support could upset this balance of interests, potentially undermining the Somaliland's stability and its significant strides towards becoming a consolidated democracy.

Given this, the international community may be tempted to attempt to scale up directlyadministered assistance in place of direct government support, but while this may be preferable to direct government support, even this approach has significant political risks that should be considered. According to a 1999 Somaliland Centre for Peace and Development report,

Local NGOs mushroomed as individuals and private enterprises sought to make themselves eligible for sub-contracts with foreign aid organizations. Many had little or no experience in the fields in which they proposed to work, and their relationships with project 'beneficiaries' were often ambiguous. The recognizable clan affiliations of most of these NGOs led to heightened competition and

${ }^{93}$ Human Rights Watch (2009), p. 22. 
sensitivity over the distribution of aid resources. Although roughly 500 local NGOs are currently registered in Somaliland, only a small minority are functional and possess a permanent organization structure. The government views this expansion of the NGO sector as a matter of concern. ${ }^{94}$

\section{General Implications for Policy in Weak and Fragile States}

One important question about this review of Somaliland's political development is whether the lessons learned in Somaliland can be more broadly applied. The number of structural factors that contributed to Somaliland's success in the absence of international engagement certainly suggest that Somaliland may not be a generalizable case: Somaliland lacked natural resources that would have reduced government dependency on local revenues even in the absence of aid; it had some degree of parity among different clans, which prevented a single group from dominating others; commercial actors had an interest in promoting peace because of the nature of pastoral economic production; and the country's relatively strong traditional institutions were able to mediate equitable agreements once resource constraints forced parties to the negotiating table.

Yet there is reason to believe that Somaliland may not be as exceptional a case as it initially appears. One theme that underlies Somaliland's political development is that government dependency on local sources of revenue forces the government to take into consideration the interests of those outside of the government -- be they the clan in control of the port of Berbera, or Isaaq businessmen providing loans to the government. This dynamic, as it turns out, also appears to have been at the heart of the development of modern, representative governments in Europe.

Researchers studying state formation in medieval Britain and the Netherlands have argued that the modern, representative state emerged as the result of negotiations between autocratic governments who needed tax revenues in order to survive inter-state conflicts on the one hand, and citizens who were only willing to consent to taxation in exchange for greater government accountability on the other. ${ }^{95}$ In these historic cases, government dependency on local sources of revenue provided those in control of economic assets with significant leverage over the government which they were able to use to demand the development of more accountable and representative political institutions though a process generally referred to as "revenue bargaining." 96 Given the similarities between these dynamics in medieval Europe and those seen in Somaliland's development, it seems reasonable to suggest that Somaliland may simply be a modern illustration of how government dependency on local revenue encourages accountability, rather than an entirely unique exception.

This similarity is important because in recent years, many have voiced concerns that foreign assistance may be disrupting this mechanism of accountability identified in European studies. This is a potentially important possibility given that in 2005 there were 16 sub-Saharan countries in which the ratio of foreign assistance to government expenditures is greater than $50 \%$, and in

\footnotetext{
${ }_{94}^{94}$ Somaliland Centre for Peace and Development (1999), p. 77.

${ }_{95}^{95}$ Moore (2008) provides an excellent overview of literature in this area.

${ }^{96}$ Both Moss, Pettersson and van de Walle (2006) provide an exceptional overview of existing literature on the relationship between this literature as it relates to modern development policy.
} 
ten of those countries, foreign assistance is equal to at least $75 \%$ of government expenditures. ${ }^{97}$ As an illustration of the fact that government dependency on local sources of revenue increases government accountability, therefore, Somaliland provides some of the most direct evidence to date that normal levels of foreign assistance have the potential to upset the "revenue bargaining" process.

\section{“Top-Down" versus "Bottom-Up" State-Building}

This analysis of Somaliland's development also has implications for the broader debate about the relative merits of "top-down" versus "bottom-up" approaches to state-building. "Top-down" approaches, which dominate most efforts in Somalia, attempt to identify a conflict's dominant political actors in a conflict and bring them to the negotiating table. Advocates of this view argue it is essential to recognize de facto power relationships, and attempt to work with them. In contrast, "bottom-up" strategies focus on fostering local engagement, either through locally selected representatives or through local political institutions.

Unsurprisingly, Somaliland has become a commonly cited example in support of "bottom-up" development. The "synergy" 98 that existed between local polities and national political reconciliation proved so successful in Somaliland, may have looked to it as a model for resolving other conflicts.

However, this analysis suggests that advocates of "bottom-up" strategies may be overlooking an important dynamic that was at play in Somaliland. Local polities in Somaliland did not pursue constructive polities simply because they were organized at the local level. They did so at least in part because of the influence of the business community which actively supported these efforts. This distinction is important because it suggests that it is not only the level of the political entity that matters, but also the interests and relationships that underly these entities. International efforts to actively finance and support local polities, which have been undertaken without success in Somalia, risk preventing the types of relationships that existed between the business community and the public sphere in Somaliland from emerging.

\section{Implications for Sequencing}

Finally, Somaliland's political development also raises difficult questions about policy sequencing in weak and fragile states. At first glance, the fact that Somaliland government spends approximately $80 \%$ of its budget on administrative costs and security strongly suggests that in the government's view, security is the clear priority for state-rehabilitation. ${ }^{99}$ And as explored in the section of this chapter on the role of the business community, Somaliland's stable environment has facilitated both economic development and relatively sophisticated publicprivate partnerships which help to provide public goods.

\footnotetext{
${ }^{97}$ Moss and Subramanian (2005), p. 4-6. Brautigam and Knack (2004) find similar numbers looking at data from the 1990s.

${ }_{98}^{98}$ Bradbury (2008), p. 107.

${ }^{99}$ War-Torn Societies Project (2005), p. 67-68.
} 
Yet Somaliland also raises the troubling idea that while prioritizing security may be in the interests of the government, efforts to promote security risk cementing the authority of unrepresentative political institutions, which may be contrary to the interests of citizens. Had the international community provided Somaliland's first interim government with the resources necessary to ensure stability, the military stand-offs which motivated political reconciliation and the negotiated development of Somaliland's political institutions would likely not have taken place. 


\section{APPENDIX ONE: Estimates of Possible Aid to Somaliland}

Had Somaliland been eligible for foreign assistance, the levels of assistance it would likely have received would have been relatively large in relation to the types of revenues currently available to the national government (\$20-40 million USD from 1999 forward, significantly less prior to that). In the paper, an estimate of \$94 million USD in constant 2005 terms is provided. However, this estimate is actually rather conservative, for three reasons. First, it is based on median rather than mean levels of foreign assistance. Second, it is calculated using a value of 2 million for Somaliland's population, when most estimates range from 2-3 million. ${ }^{100}$ And third, it does not take into account the well documented tendency for donors to provide higher levels of aid per capita to smaller countries. This appendix provides a number of alternative estimates that provide a slightly more nuanced sense of the volumes of aid Somaliland might have received had it been eligible.

\section{Data}

Population data comes from the World Development Indicators database. Aid data comes from the Net Aid Transfers dataset published by the Center for Global Development. ${ }^{101}$ This data draws from the OECD DAC data on aid activities, but makes a few of corrections to data from the OECD so they better reflect actual financial transfers, rather than changes in a country's capital positions. ${ }^{102}$

This analysis also excludes the island country of Mayotte, which has a population of less than 200,000 people and which receives foreign assistance in excess of \$1,000 USD per capita. This exclusion is justified both by patchy data availability for the country, and also by the way it skews estimates of aid intensity both generally and in particular for smaller countries. This exclusion results in more conservative estimates of foreign assistance to Somaliland.

\section{Summary Statistics}

\footnotetext{
${ }^{100}$ Statistics on Somaliland's population vary, but most estimates cluster around 2-3 million. A detailed summary of Somaliland population surveys can be found in a footnote in Bradbury (2008), p160.

${ }_{101}$ Available at http://www.cgdev.org/content/publications/detail/5492

102 "The Net Aid Transfers (NAT) variable alters two aspects of the standard Net Overseas Development Assistance (Net ODA) measure that can be problematic for aid research and donor evaluation. First, where Net ODA is a capital flow concept, analogous to Net Foreign Direct Investment, NAT is a net transfers concept. That is, Net ODA is net only of principle payments received on ODA loans, not of interest received on such loans, while NAT is net of both. This is especially relevant for Japan, which has received more than $\$ 2$ billion/year in interest on ODA loans recently. Second, NAT excludes cancellation of old non-ODA loans. For example, a 2003 Paris Club agreement cancelled some $\$ 5$ billion in non-ODA official debt owed by the Democratic Republic of Congo. That cancellation is ODA, but since it generated little or no additional net transfers, it is not NAT. As a result, the DRC received \$5.4 billion in ODA in 2003 but only $\$ 400$ million in NAT." (Center for Global Development Net Aid Transfer Dataset Abstract)
} 


\begin{tabular}{lcccccc}
\hline \multicolumn{1}{c}{ Variable } & Obs & Mean & Median & Std. Dev. & Min & Max \\
\hline $\begin{array}{l}\text { Country Average of } \\
\text { Net Aid Transfers Per Capita } \\
\text { between 1999 and 2004 } \\
\text { (in Constant 2005 Dollars) }\end{array}$ & 47 & 48.6 & 33.6 & 55.8 & 2.26 & 291.7 \\
$\begin{array}{l}\text { Country Average of } \\
\begin{array}{l}\text { Net Aid Transfers Per Capita } \\
\text { between 1991 and 2004 } \\
\text { (in Constant 2005 Dollars) }\end{array}\end{array}$ & 47 & 64.5 & 46.7 & 69.0 & 2.4 & 358.3 \\
$\begin{array}{l}\text { Average Population between 1991 and 2004 } \\
\text { (in millions) }\end{array}$ & 47 & 11.2 & 6.3 & 16.9 & 0.1 & 97.2 \\
\hline
\end{tabular}

\section{Correcting for Country Size}

Most studies of the determinants of foreign assistance finds that smaller countries receive higher levels of aid per capita, perhaps because of the desire of aid agencies to maintain a presence in all countries, including very small ones (Brautigam and Knack (2004) and Knack (2009) for example). To correct for this possibility, aid per capita can be regressed against country populations and annual fixed effects for the sub-Saharan African region from 1990 to 2004, and values can then be predicted based on Somaliland's population both for the entire period, and for certain specific years. These regressions also include a dummy for each country's historic colonial relationships, as some studies have also found this to be a significant predictor of aid levels (Brautigam and Knack (2004), Rajan and Subramanian (2005a)). ${ }^{103}$

As in previous estimates, these results assume a population value of 2 million for Somaliland. While this will result in larger estimates of aid per capita than an estimate of 3 million, the estimates of overall assistance remain lower with a population estimate of 2 million than 3 million. Because of limited data on Somaliland, these regressions will only use the natural $\log$ of population, historic colonial relationships, and annual fixed effects.

Net Aid Transfers Per Capita

As a Function of Population, Historic Colonial Relationship, and Year

Dependent

Variable

103 Regressions were also run without colonial relationship fixed effects, but the estimates were higher for Somaliland, so in the interest of presenting conservative estimates, colonial fixed effects were left in place. 


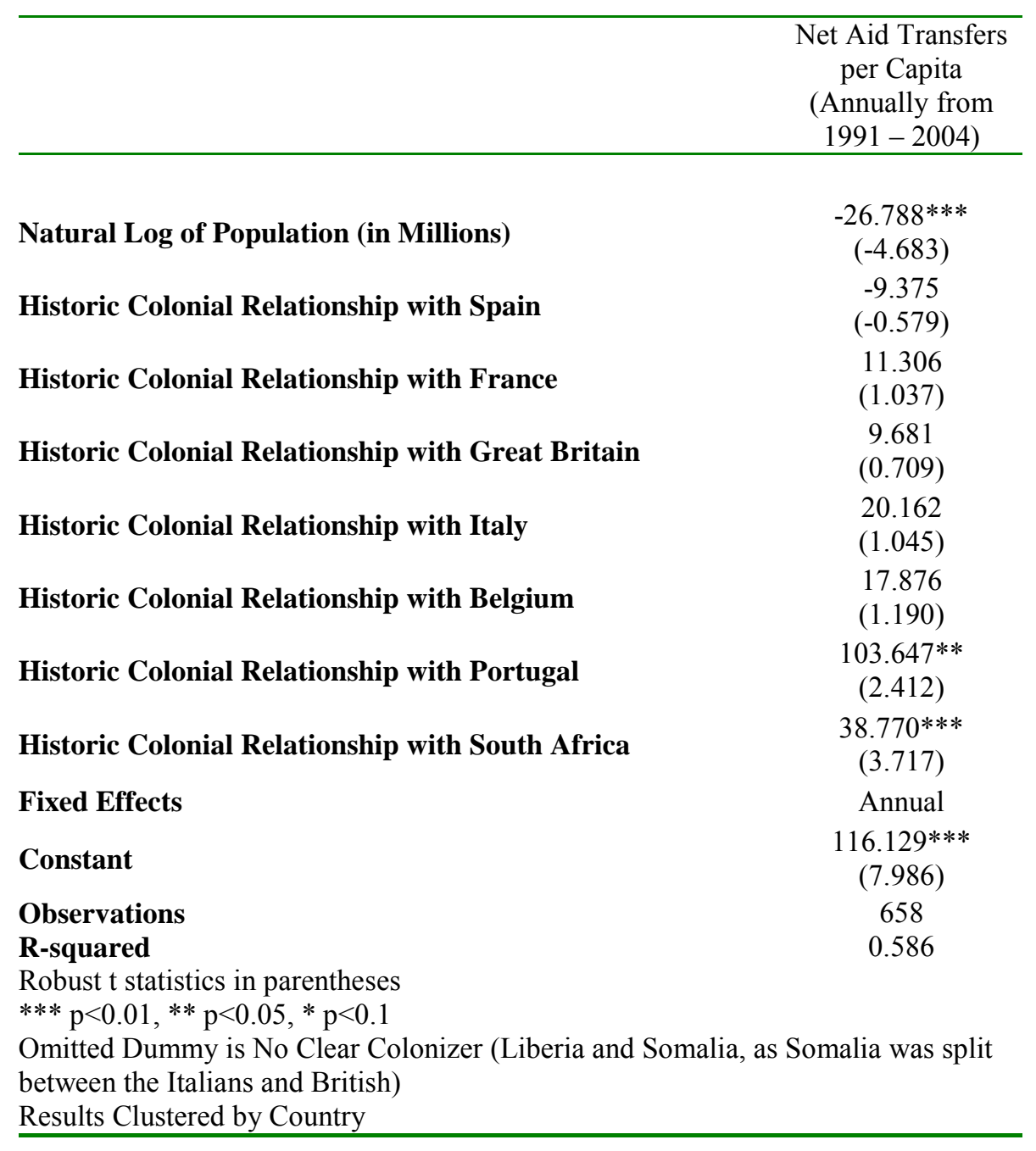

Based on these regressions, estimates of likely levels of aid per capita can be predicted for Somaliland. The following table provides estimates of aid per capita for various periods, and for specific years.

Predicted Values

Controlling for Population, Past Colonial Relationships, and Annual Fixed Effects

Period

1991-2004 Average
Net Aid Transfers Per Capita
Total Aid

For Population of 2 Million

$\$ 79.2 \quad \$ 158.4$ million USD


1999-2004 Average

Year of Secession (1991)

Year of Boorame Conference (1993)

Year of Hargeysa Conference (1997)

Year Constitution Ratified (2001)

All figures in Constant 2005 Dollars. Predictions based on regres population and dummy variables for historical colonizer. Values of aid per capita for Somaliland were predicted on

the basis of a population of 2 million.

$\$ 66.1$

$\$ 107.2$

$\$ 98.6$

$\$ 75.9$

$\$ 66.7$
\$132.3 million USD

$\$ 214.5$ million USD

$\$ 197.2$ million USD

$\$ 151.9$ million USD

\$133.4 million USD 


\section{APPENDIX TWO: \\ Empirical Evidence for \\ Effectiveness of Fiscal Decentralization}

One empirical measure of fiscal decentralization is whether local government revenues are correlated with national revenues. Data from Somaliland suggests that the success of fiscal decentralization has been mixed -- on the whole, it appears most local groups depend on the national government for financial support. However, the revenues of four municipalities in Somaliland show a great deal of independence, suggesting fiscal decentralization has succeeded in those settings (perhaps due to greater presence of local businesses to tax than in the average community). This is shown in the two graphs below. The choice of municipalities included in the graphs below is dictated by data made available by the Ministry of National Planning and Coordination's Somaliland in Figures publication (this data comes from both the 2004 and 2008 editions). ${ }^{104}$ All expenditure data included in those reports is reproduced here.
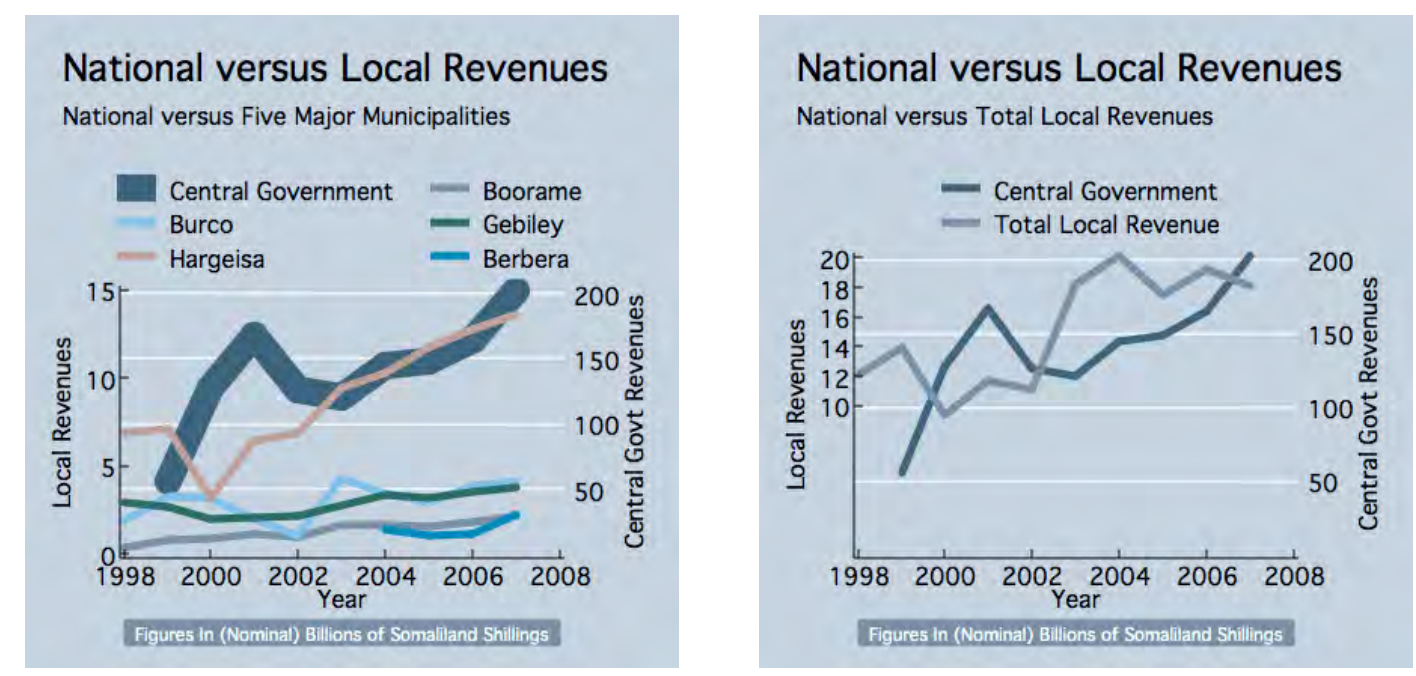

Correlation of Municipal Expenditures with Central Government Expenditures

\begin{tabular}{ccc}
\hline Municipality & $\begin{array}{c}\text { Simple Correlation of Municipal and } \\
\text { Central Government Expenditures }\end{array}$ & $\begin{array}{c}\text { Number of } \\
\text { Years of Data }\end{array}$ \\
\hline Hargeisa & 0.54 & 9 \\
Gebiley & 0.43 & 8 \\
Boorame & 0.72 & 9 \\
Burco & 0.15 & 9 \\
Berbera & 0.87 & 4 \\
All Local Expenditures Combined & 0.32 & 9 \\
\hline
\end{tabular}

\footnotetext{
${ }^{104}$ The Somaliland in Figures version from 2004 differs from the Somaliland in Figures version for 2009 in its estimate of central government expenditures for 2003. This data reflects the 2009 value, which is more recent and appears more in line with later budgets.
} 


\section{BIBLIOGRAPHY}

Bernstein, Thomas and Xiaobo Lu. (2008) "Taxation and coercion in rural China." in Brautigam, Fjeldstad and Moore (eds.) (2008) Taxation and state-building in Developing Countries Cambridge University Press, New York. p. 89-113.

Bulhan, Hussein Abdilahi. (2004) Somaliland in Ruin and Renewal: The Story of Somaliland. Conflict Analysis Regional Report, Center for Creative Solutions. September.

Boone, Peter. (1996) "Politics and the Effectiveness of Foreign Aid." European Economic Review. vol. 40, no. 3. p. 289-329.

Bradbury, Mark. (2008) Becoming Somaliland. African Issues, Progresio, London.

Brautigam, Fjeldstad and Moore (eds.) (2008) Taxation and state-building in Developing Countries Cambridge University Press, New York.

Brautigam, Deborah and Knack, Stephen. (2004) "Foreign Aid, Institutions, and Governance in Sub-Saharan Africa." Economic Development and Cultural Change. vol. 52, no. 2. p. 255-285.

Burnside, Craig, and Dollar, David. (2000) “Aid, Policies, and Growth.” American Economic Review. vol 90, no. 4. P. 847-868.

Clemens, Radelet, and Bhavnani (2004). "Counting chickens when they hatch: The short term effect of aid on growth.” Center for Global Development Working Paper Series \#44.

De Waal, Alex. (2007) "Class and Power in a Stateless Somalia," SSRC Crisis in the Horn of African Web Forum. February. http://hornofafrica.ssrc.org/dewaal/index.html

Djankov, Montalvo, and Reynal-Querol. (2005) "The curse of aid," Economics Working Papers \#870. http://ideas.repec.org/p/upf/upfgen/870.html\#provider

Drysdale, John. (1995) Problems of Decentralization and Suggested Approaches, Ministry of Interior, Republic of Somaliland.

Easterly, William; Levine, Ross; and Roodman, David. (2004) “Aid, Policies, and Growth: Comment” American Economic Review, vol. 94, no. 3, p. 774-780.

Farah, Ahmed. (1999) "Civil-Military Relations in Somaliland and Northeast Somalia" Presented at the Conference on Civil-Military Relations in Nairobi. April.

http://www.somaliawatch.org/archivefeb01/010414202.htm

Farah and Lewis (1993) Somalia: The Roots of Reconciliation, ActionAid.

Gupta, Clements, Pivovarsky, and Tiongson. (2004) "Foreign Aid and Revenue Response: Does the Composition of Foreign Aid Matter?" in Gupta, Clements and Inchauste (eds.). (2004) 
Helping Countries Develop. The Role of Fiscal Policy. Washington, DC: International Monetary Fund.

Holleman, C. F. (2002) "Some problems in African Conflict Resolution: Reflections on Alternative Reconciliation Work and Research." Internet edition: NomadNet. Cited in Bradbury (2008).

Human Rights Watch (2009) "Hostages to Peace: Threats to Human Rights and Democracy in Somaliland."

International Crisis Group (2003) "Somaliland: Democratization and its Discontents,", Crisis Group Africa Report No. 66.

International Crisis Group (2009) "Somaliland: A Way out of the Electoral Crisis,", Africa Briefing No. 67.

Jensen, N. and Wantchekon, L. (2004) "Resource wealth and Political Regimes in Africa", Comparative Political Studies 37. p. 816-841.

Knack, Stephen. (2009) "Sovereign Rents and Quality of Tax Policy and Administration." Journal of Comparative Economics, Volume 37, Issue 3, September. p. 359-371.

Mahon, Jeffrey (2004) "Causes of Tax Reform in Latin America, 1977-95", Latin American Research Review vol. 39, no.1. p. 3-30.

Mahon, Jeffrey (2005). "Liberal States and Fiscal Contracts: Aspects of the Political Economy of Public Finance" Prepared for delivery at the 2005 Annual Meeting of the American Political Science Association, September 1-4.

Mehlum, Halvor, Moene, Karl, Torvik, Ragnar. (2006) "Institutions and The Resource Curse." Economic Journal 116. p. 1-20.

Menkhaus, Ken. (2001) "Traditional Conflict Management in Contemporary Somalia," in Zartman, (eds.) Traditional Cures for Modern Conflicts, SAIS African Studies Library, p. 183199.

Menkhaus, Ken. (2006/2007) "Governance without Government in Somalia: Spoilers, State Building, and the Politics of Coping." International Security, Vol. 31, No. 3.

Moore, Mick. (2008) "Between coercion and contract" in Brautigam, Fjeldstad and Moore (eds.) (2008) Taxation and state-building in Developing Countries Cambridge University Press, New York. p. 34-63.

Moss, Pettersson, and van de Walle (2006) "An Aid-Institutions Paradox? A Review Essay on Aid Dependency and State Building in Sub-Saharan Africa." Center for Global Development Working Paper Series \#75. 
Moss and Subramanian. (2005) "After the Big Push? Fiscal and Institutional Implications of Large Aid Increases.” Center for Global Development Working Paper Series \#71.

North and Weingast (1989) "Constitutions and Commitment: Evolution of Institutions Governing Public Choice in 17th Century England" Journal of Economic History, XLIX no.4. p. 803.

Prendergast, John. Frontline Diplomacy: Humanitarian Aid and Conflict in Africa. Lynne Rienner Publishers, Boulder, Colorado, 1995.

Rajan, Raghuram and Subramanian, Arvind. (2005a) "Aid and Growth: What Does the CrossCountry Evidence Really Show?” NBER Working Paper Series \#11513.

Rajan, Raghuram and Subramanian, Arvind. (2005b) "What Undermines Aid's Impact on Growth?” IMF Working Paper Series \#05/126.

Reno, W. (2003) Somalia and Survival in the Shadow of the Global Economy. Queen Elizabeth House Working Paper 100. Oxford and Northwestern University.

Robinson, Torvik, and Verdier. (2006) "Political foundations of the resource curse." Journal of Development Economics, 79, p. 447-468.

Ross, M. I. (2001) “Does Oil Hinder Democracy?”, World Politics 53. p. 325-61.

Somaliland Centre for Peace and Development (1999) "A Self-Portrait of Somaliland: Rebuilding from the Ruins." December.

Somaliland Ministry of Planning and Coordination (2004). "Somaliland in Figures (2004)." Available at: http://siteresources.worldbank.org/INTSOMALIA/Resources/somaliland in_figures_04.pdf

Somaliland Ministry of Planning and Coordination (2008). "Somaliland in Figures (2008)." Available at: http://slministryofplanning.org/index.php?option=com content\&task=blogsection\&id=37\&Itemi $\underline{\mathrm{d}=58}$

Tilly, Charles. (1992) Capital, Coercion, and European States, AD 990-1992. Basil Blackwell, Cambridge MA.

Timmons, J.F. (2005) “The Fiscal Contract, States, Taxes, and Public Services” World Politics vol. 15 , no. 4. p. 530-567.

UNDP/World Bank (2003). "Socio-Economic Survey 2002: Somalia," Somalia Watching Brief, Report No. 1. 
War-Torn Societies Project (2005) Rebuilding Somaliland: Issues and possibilities. The Red Sea Press, Lawrenceville, NJ.

Zartman, William (eds.) Traditional Cures for Modern Conflicts, SAIS African Studies Library, 2001, p. 197. 